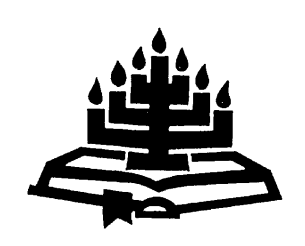

\title{
Die liggaam-van-Christus-metafoor: instrument vir die effektiewe uitvoering van die missionale opdrag
}

\author{
J.M. Olwagen \\ Fakulteit Geesteswetenskappe \\ Universiteit van Johannesburg \\ JOHANNESBURG \\ E-pos: koelma@telkomsa.net \\ M. Nel \\ Skool vir Bybelwetenskappe \& Bybeltale \\ Potchefstroomkampus \\ Noordwes-Universiteit \\ POTCHEFSTROOM \\ E-pos: maiusnel1@mweb.co.za
}

\begin{abstract}
The body-of-Christ-metaphor: instrument for the effective execution of the missional commission

Practice suggests that many AFM pastors are possibly so busy with numerous tasks and responsibilities that they are unable to effectively mobilise their assembly members to actively participate in voluntary acts of service (cf. Eph. 4:12). The consequence is that such assemblies are often unable to function effectively in the carrying out of the missional commission (according to Matt. 28:19). Pastors are unsuccessful in working more effectively through the mobilisation of their members as part-time voluntary workers in the carrying out of the missional commission, according to the advice Moses' father-in-law gave him (cf. Ex. 18).

The mobilisation of members takes place through the empowering of members to discover and develop their gifts and allowing their involvement in voluntary acts of service. The emphasis of this article lies in what Hendriks (2004:11) calls "congregational theology". According to Hendriks (2004:25) congregational theology is a theology being practised by body-of-Christ-metaphor assemblies (cf. Eph. 4:11-16). The metaphor of assemblies choosing to function as the body-of-Christ where the
\end{abstract}


importance of the voluntary acts of service of members is emphasised enjoys further development in this article.

\section{Opsomming}

Die liggaam-van-Christus-metafoor: instrument vir die
effektiewe uitvoering van die missionale opdrag

Die praktyk toon dat baie AGS-pastore moontlik so besig is met 'n veelheid take en verantwoordelikhede dat hulle nie daarby uitkom om hulle gemeentelidmate effektief te mobiliseer om by vrywillige dienswerk betrokke te raak nie (vgl. Ef. 4:12). Die gevolg is dat sulke gemeentes dikwels nie effektief funksioneer om die missionêre opdrag met welslae uit te voer nie ( $\mathrm{vgl}$. Matt. 28:19). Pastore slaag nie daarin om, volgens die raad wat Moses se skoonvader vir hom gegee het (vgl. Eks. 18), meer effektief te werk deur hulle lidmate as deeltydse vrywillige dienswerkers te mobiliseer om die Bybelse opdrag uit te voer nie.

Die mobilisering van lidmate vind plaas deur lidmate te bemagtig om hulle gawes te ontdek en te ontwikkel, en dan daarmee saam vrywillige dienswerk te beoefen. Die klem in die artikel lê by wat Hendriks (2004:11) "gemeentelike teologie" noem. Volgens Hendriks (2004:25) is gemeentelike teologie 'n teologie wat deur die liggaam-van-Christus-metafoorgemeentes beoefen word (vgl. Ef. 4:11-16). Die metafoor van gemeentes wat as liggaam-van-Christus wil funksioneer, naamlik gemeentes wat die belangrikheid van vrywillige dienswerk van die lidmate beklemtoon, geniet verdere ontwikkeling in hierdie artikel. 1

\section{Inleiding}

Tradisioneel is gemeentes in die AGS volgens die herder-kuddemetafoor ingerig, waar die pastoor die meeste van die werklas dra (vgl. Eks. 18:17-23). In die tradisionele herder-kuddemetafoorgemeente word die persepsie geskep dat die pastoor saam met sekere leiersfigure, alleen vir al die werk verantwoordelik is.

Waar die funksie van die gemeente eksklusief gerig word op die versorging van lidmate, val die klem op die taak van die pastoor. Lidmate kry nie die geleentheid om self vrywillige dienswerk, hetsy binne gemeentelike of missionêre verband, te verrig nie en dus kan die missionêre opdrag nie na behore uitgevoer word nie. Die term

1 Vergelyk Goede (2007:87-107) vir 'n breedvoerige verduideliking van 'n toepaslike metafoorteorie. 
missionêr beklemtoon die noodsaaklike aard en doel van die kerk as God se geroepe en gestuurde instrument om alle mense met sy liefde te bereik (Guder, 1998:11).

Waar gemeentes hulle lidmate se gawes, talente en bekwaamhede benut om dienswerk te verrig, vind 'n paradigmaskuif plaas sodat gemeentes hulle missionêre opdrag kan uitvoer (Bisschoff, 1993: 42).

Die beginsel dat die kerk as liggaam-van-Christus tot geestelike volwassenheid en gestalte moet groei, is 'n Bybelse opdrag. Richards en Hoeldtke (1981:46) verduidelik in hul bespreking van die kerk as liggaam-van-Christus dat die kerk soos 'n organisme is, wat bestem is om te groei. Die proses van groei behels die gesamentlike bydrae wat elke lid individueel lewer sodat die geheel opgebou kan word en individue geestelike volwassenheid kan bereik.

\section{Liggaam-van-Christus-metafoor}

\subsection{Verklaring van begrip}

Institusies soos die kerk toon die geneigdheid, deur hulle manier om dinge te doen, om rigied en stagnant te word soos dit groei, ouer word en gevestig raak. Dit ontwikkel eie gemaksones en magstrukture met eksplisiete of implisiete hiërargieë van mag wat in stand gehou word. Mettertyd vind sodanige strukture dit moeilik om aan te pas of te verander. Die leierskap daarvan is ook op mag gesteld en verloor tred met die behoeftes van mense wat gedien behoort te word.

Met die ontwaking van humanisme en demokratiese regerings het die Renaissance en die moderne Westerse kultuur die "top-down"manier van dink en die vorming van strukture uitgedaag deur 'n "botttom-up"-tendens. Sinodale en denominasionele strukture het variasies van hiërargiese gesag gevorm. Hiërargiese gesag verwys na gesag wat volgens rangorde beoefen word. In die institusionele model waarvan die Rooms-Katolieke Kerk die beste voorbeeld is, word van priesterlike gesag gepraat. Die gesag word beoefen deur die struktuur van bo na onder. Die gevolg is dat lidmate geestelik onvolwasse en onbetrokke ten opsigte van die kerk se missie raak.

Die basiese behoefte aan gemeenskap, en die afwesigheid daarvan in die "top-down"- kerkmodel, het die weg vir 'n invloedryke metafoor met 'n nuwe styl gebaan. Die liggaam-van-Christus-metafoor kan die nuwe identiteit verduidelik. 
Sonder om aan die waarde van ander modelle afbreuk te doen, meen Heyns (1977:51) dat dit hier om 'n metafoor gaan waarin die rykste betekenisskakerings voorkom, en daarom is dit vir die verstaan van die kerk van die allergrootste belang.

Die liggaammetafoor speel 'n belangrike rol in Pauliniese teologie alhoewel dit nie op baie plekke in sy briewe voorkom nie (Van den Berg, 2000:26). Die metafoor word dwarsdeur die Efesiërbrief gebruik: Alle gelowiges vorm saam die liggaam van Christus en doen die werk waartoe Christus hulle roep (Janse van Rensburg, 1999: 1569-1570).

Beker (1989:307-308) meen dat Paulus se beeld van die liggaam 'n kragtige beeld is wat nie bloot die verskillende aspekte van deelname as grondidee verkort of opsom nie, maar ook die idee van onderlinge interafhanklikheid in die lewe van die kerk uitdruk.

\subsection{Liggaammetafoor as 'n lewende organisme}

Die liggaam is 'n lewende organisme wat kan groei of kwyn (Van den Berg, 2000:37). Die metafoor spreek van lewe in die kerk, omdat elkeen besig moet wees om die gawe wat hulle ontvang het, in belang van die geheel aan te wend (vgl. Rom. 12; 1 Kor. 12; Ef. 4). As liggaam is die kerk 'n organies-werkende geheel waarin alle lede hulle plek tot heil van die geheel moet volstaan.

Volgens Murphy (1975:308) funksioneer die gemeente as 'n liggaam wanneer elke lid as belangrik geag word en lidmate hulle eiesoortige, unieke funksies verrig. Warren (1995:13-17) meen dat die gesondheid van 'n gemeente aan die vlak van lidmaatbetrokkenheid gemeet kan word. Die groei en opbou van die kerk word deur die deelname van elke lid in gemeenskap met Christus bevorder.

\subsection{Liggaammetafoor vir dienslewering}

Die kerk as liggaam is nie net 'n organisme wat deur Christus geskep en onderhou word nie, maar wat Hy ook gebruik tot dienslewering. Die kerk as liggaam is die instrument waardeur Jesus Christus Hom tot die wêreld rig (Heyns, 1977:57-58). Die kerk se roeping as liggaam van Christus is om diens te lewer - diens aan God, kerk en samelewing.

Vir die uitvoering van die diensleweringstaak, gee Christus deur sy Gees die nodige gawes aan die liggaam en sy lede. Paulus illustreer die verskeidenheid gawes in Romeine 12:6-8, 1 Korintiërs 12:8-10, 28-30 asook Efesiërs 4:11 (Langerman, 1983:214; Van den Berg, 
1991:22). Die liggaam-van-Christus-metafoor veronderstel dat die ideaal vir 'n gemeente is dat elke lidmaat besig sal wees met die dienswerk wat God vir hulle bedoel het.

\subsection{Kernteologiese bespreking}

Die liggaammetafoor beklemtoon gemeenskap met mekaar en met God in Christus, waarbinne die Heilige Gees 'n fundamentele rol speel. Die konsep van die gemeente as liggaam van Christus baan die weg vir 'n kommunikasiestruktuur binne die gemeente waarin alle lidmate op gelyke vlak in die gemeente betrokke kan raak. Die geleentheid word aan lidmate gebied om die genadegawes soos deur die Heilige Gees aan hulle gegee, te beoefen.

\subsection{Vrae rondom die metafoor}

Die metafoor stel die volgende vrae:

- Hoe word eenheid tussen lidmate bereik?

- Wie word deur die metafoor bevoordeel?

- Wat is die doel of missie van die metafoor?

Die vrae word soos volg beantwoord:

- Eenheid word bereik deur lidmate wat van hulle geloof in Christus getuig en deur die teenwoordigheid van die Heilige Gees en sy gawes.

- Lidmate wat wedergebore is, die Heilige Gees asook die gawes wat Hy gee, ontvang het, is bevoordeel omdat hulle nou deel van die liefde en die gemeenskap in die liggaam is. Daarmee saam bevoordeel die metafoor alle ander lidmate, sowel as mense wat die teiken van die kerk se uitreiking vorm, omdat die funksionering van die gemeente as die liggaam-van-Christus-metafoor meer effektief plaasvind.

- Die doel of missie (Hendriks, 2004:50) is 'n persoonlike verhouding met Christus en die Heilige Gees deur gemeenskap met God, wat lei tot gemeenskap met ander gelowiges in die liggaam.

\subsection{Beoordeling van die metafoor}

Woods (1996:108) wys daarop dat die belangstelling in die ontwikkeling van die diens van die gelowige sedert 1950 begin toeneem het. Hierby kan gewys word op die feit dat die bekende missioloog, Kraemer (1958:161), reeds in 1958 gepleit het vir 'n 
"theology of the laity" waarin die gelowiges se dienswerk beskou word as 'n onvervreembare taak wat die Here aan hulle opgedra het.

Louw (1990:220-221) spreek sy kommer uit oor die wyse waarop deeltydse werkers hulle eie betrokkenheid by die gemeente interpreteer. Daar bestaan 'n wesenlike verskil tussen kerkwees geïnterpreteer as 'n gondel (een roei terwyl die ander insittendes die landskap geniet) en as 'n roeiboot (almal roei saam as 'n span en stuur op 'n gemeenskaplike doelwit af).

Alhoewel daar onbetrokke, selftevrede, passiewe lidmate in die kerkbanke sit, is daar ook heelwat ander lidmate wat alreeds tot volwassenheid gegroei het en vir wie die tradisionele model van kerkwees ontoereikend en frustrerend is. Daar behoort indringend aandag aan die toerustingsrol van die besondere dienste (vgl. Ef. $4: 12$ ) in die kerk geskenk te word. Gelowiges behoort veral vir die vervulling van 'n sendingroeping toegerus te word.

Die positiewe aspek van die metafoor is dat dit 'n sterk Bybelse basis het wat gemeenskap met mekaar en met God beklemtoon. Die klem op lidmate se betrokkenheid het tot gevolg dat hulle by die ekumene betrokke raak. 'n Verdere positiewe uitwerking van die metafoor is dat daar opnuut oor die bediening van die lidmaat besin word. Kerk en bedieningstrukture het gevolglik merkwaardige veranderings ondergaan in vergelyking met vorige modelle. Die metafoor sien mense nie primêr en bloot as sondaars nie, maar as mense wat gered is en deur God gebruik kan word. God word gesien as naby, as die liefdevolle Vader wat in sy mense woon deur sy Gees. Spiritualiteit, 'n gebedslewe, reiniging tot redding en persoonlike gemeenskap, wat 'n behoefte in die moderne Westerse kapitalistiese kultuur se funksionele etos blyk te wees, word weer opnuut deur die metafoor beklemtoon.

Die metafoor het ook bepaalde nadele. In reaksie teen dooie ortodoksie kan die metafoor ekstremisties raak met betrekking tot die gebruik van gawes van die Heilige Gees. Indien die gebruik van die gawes van die Heilige Gees nie in balans gehou word met die leer aangaande die Godheid nie, kan dit tot allerlei dwalinge aanleiding gee wat uiters skadelik vir die lidmate is (vgl. 1 Kor. 12). Wanneer die bediening van die lidmaat oorbeklemtoon en die rol van leierskap genegeer word, mag dit tot dwaalbegrippe lei. Verklarings soos: "Die Here het vir my gesê", word geredelik gemaak. Die gevolg mag wees dat ware onderskeiding nie kan plaasvind nie. Die toepassing van die metafoor mag nie die sondige natuur van die 
mens afmaak en te veel klem lê op die mens as die geseëndes van die Here nie. Hierdie geseëndes van die Here leef dan in 'n illusionêre wêreld van seën, waar die begrip van die kruis en lyding geïgnoreer word.

In pinkster- en charismatiese geledere word die organisatoriese en strukturele soms gesmoor omdat subjektiwiteit en individualisme teenstrydig samewerking en eenheid in gevaar stel. As sodanig, toon die liggaam-van-Christus-metafoor dikwels 'n gebrek aan 'n duidelike begrip van identiteit, missie en suiwer eskatologie (Hendriks, 2004:51).

In gemeentebouteologie word van 'n paradigmaverskuiwing ten opsigte van die verstaan van die kerk gepraat (Louw, 1990:3). So 'n verskuiwing vervang die statiese herder-kuddemodel met die dinamiese liggaam-van-Christus-metafoor van kerkwees (Hendriks, 1992:123). Ofskoon die kerk in die Nuwe Testament aan die hand van 'n rykdom beelde of metafore getipeer word (vgl. Joh. 15; Rom. 11:16; 1 Kor. 3:6-10; 2 Kor. 3:2-3; 11:2; Ef. 2:19, 21; 5:22-25), is dit veral die liggaammetafoor wat telkens in die literatuur bespreek word, omdat die metafoor verskeie moontlikhede bied met die oog op doeltreffende gemeentefunksionering (Hendriks, 1992:123; Louw, 1992:125; Nel, 1994:243). Die benutting van 'n metafoor in hierdie verband lei tot 'n modellering en konseptualisering van 'n aangepaste gemeentemetafoor vanuit die doelwitte van die gemeente en die dienswerk van die gelowige (Louw, 1992:121).

Van den Berg (1991:13-16) stel die liggaam-van-Christus-metafoor as ' $n$ bedieningsmodel vir gemeentes voor. Hy is van mening dat:

- die liggaam-van-Christus-metafoor as bedieningsmetafoor die beste uitdrukking gee aan die plan en wil van God vir die funksionering van sy gemeente en die effektiewe uitvoering van die missionêre opdrag (vgl. byvoorbeeld Matt. 28:19);

- dit die nadele van institusionalisering die beste teëstaan en neutraliseer;

- waar gemeentes die metafoor as bedieningsmodel gebruik, die grootste en mees dinamiese kerkgroei, kwalitatief en kwantitatief, plaasvind. Die rede daarvoor is dat meer mense by die dienswerk betrokke is. 


\subsection{Christus as hoof van die liggaam}

Christus bestaan afsonderlik en onafhanklik van die kerk, maar staan terselfdertyd ook in verbintenis tot die kerk in die sin dat die kerk nie sonder Hom kan bestaan nie.

Die beeld van Christus as hoof van die liggaam dui daarop dat die kerk meer is as bloot ' $n$ institusionele organisasie. Die kerk is ook ' $n$ organisme, bestaande uit gelowiges wat saamwerk en vir mekaar omgee te midde van hulle verhouding met Christus as die Hoof (Van den Berg, 1991:16-17). Die lewe van die liggaam vloei vanaf die Hoof, en gelowiges is deur die Heilige Gees aan mekaar verbind.

\subsubsection{Lidmate as deel van die liggaam}

Gelowiges word in gemeentelike verband korporatief behandel en nie van hulle individualiteit ontneem nie. Alle gelowiges in die liggaam besit afsonderlik ' $n$ eie identiteit, verpligting en taak (vgl. 1 Kor. 12:12-31; Ef. 4:7), alhoewel daar nie van individualisme sprake mag wees nie. Gelowiges vind hulle ware identiteit eers binne die Christelike gemeenskap.

Die begrip lidmaatskap kom as sodanig nie in die Bybel voor nie. Gelowiges word binne die konteks van die liggaam-van-Christusmetafoor lede van die liggaam genoem en is gelyk voor die Here. In gevalle waar lidmaatskap in die Nuwe Testament voorkom, word dit gebruik om na die gelowige te verwys as lid van die gemeente binne die metafoor van die kerk as liggaam-van-Christus (vgl. 1 Kor. 12:27; Rom. 12:5; Ef. 4:16). Gelowiges word lede van die kerk genoem soos wat liggaamsdele lede van die liggaam is (Lazenby, 1995:16). Daar is egter lidmate wat vir besondere gawes geroep is (vgl. Ef. 4:11), naamlik om die gelowiges juis toe te rus vir hulle dienswerk (vgl. Ef. 4:12).

Die term leek word nie in hierdie artikel gebruik nie, omdat dit vir misverstande vatbaar is. Kraemer (1960:47) stel:

Het woord 'leek' gaat terug op het Griekse woord 'laikos', dat in zijn verlatijnse vorm 'laicus' zijn intrede heeft gedaan in tal van Westerse talen. Het is als een door en door godsdienstig woord dat 'laicus' deel gaan uitmaken van de grootste traditie van het Westen. Oorspronkelijk betekent het behorend tot de 'laos', dat is het uitverkoren volk Gods, zowel in het Oude als het Nieuwe Testament. Bij dat licht bezien, zijn de lede van de kerk 'laikoi' en alleen op deze grondslag kunnen zij nader worden omschreven. Het is van belang op te merken dat het woord 'leek' met zijn oorspronkelijk zuiwer godsdiensige betekenis ... geheel 
gesekulariseerd zijn. In gewone spraakgebruik betekent 'leek': niet bevoegd tot spreken en oordelen op allerlei terreinen van kennis en wetenschap.

Om hierdie rede word dié term nie benut nie - lidmate is nie onbevoeg vir die taak waarvoor die Here hulle roep nie. Leke word dikwels in die volksmond as onwetend en geestelik onvolwasse beskou. Dié siening mag daartoe lei dat lidmate verval in die leke-rol van onaktiewe meelopers (Van den Berg, 2000:37). Die term lidmaat word eerder verkies. Lidmate wat hulle eie identiteit as Christene ken, sal ook lidmate wees wat met 'n totale verbintenis (commitment) aan die diens van die Here van die kerk gewy is en met betroubaarheid (accountability) hulle roeping en taak as lede van die ekklesia vervul (Van den Berg, 2000:59).

Die AGS maak 'n onderskeid tussen amptelike en nie-amptelike lidmaatskap. Vir administratiewe doeleindes is slegs gedoopte lidmate amptelik lidmate van die AGS. Die grootte van die gemeente word ook bepaal deur die aantal gedoopte lidmate. Volgens die Bybel is dit duidelik dat mense slegs in een van twee groeperinge val: dié wat Christus as Saligmaker aanvaar het, en dié wat Hom nie aanvaar het nie. In verskeie AGS-gemeentes is daar egter belangstellende mense wat nog nie gedoop is nie, maar wat hulle met die gemeente assosieer en hulself as lidmate van die gemeente beskou. Die pastoor van die plaaslike gemeente versorg derhalwe ook hierdie lidmate. Strategieë behoort in plek gestel te word om alle mense, hetsy "amptelike" of "nie-amptelike" lidmate, op te neem in 'n potensiaalontwikkelings- en toerustingsmetafoor wat hulle in staat sal stel om hulle gawes te ontdek en te mobiliseer - sodoende kan hulle ten volle deel van die liggaam wees. Daar mag moontlik in die "nie-amptelike" groep lidmate ook mense met talente, gawes en vaardighede wees wat met groot welslae aangewend kan word tot bevordering van die Koninkryk.

\subsubsection{Roeping van die liggaam}

Liggaamsgroei vind plaas waar gelowiges as 'n eenheid saamgevoeg is en hulle eie unieke funksies vervul. Vanuit Combrink en Venter (1995:592) se analise van die Kolossensebrief blyk dit dat God lidmate wil gebruik in die opbou van die gemeente.

Tans het die mondigheid van die gemeente sterk op die voorgrond getree sodat daar selfs van 'n tweede hervorming gepraat word. Die eerste hervorming het die Skrifwoord in die hande van die gelowiges teruggeplaas. Die tweede wil die dienswerk in hulle hande plaas 
(Heyns \& Pieterse, 1990:2). Gemeentelede is egter dikwels nie toegerus om dienswerk te verrig nie. Dit is die gevolg van die tradisionele bedieningstruktuur waarin die pastoor die bediening in die gemeente oorheers het. Mondigheid word bewerkstellig waar die gemeente lidmate se gawes ontdek en hulle tot selfstandige optrede ontwikkel het.

Dit was veral Kraemer wat stukrag aan die tweede hervorming gegee het. Deur middel van onderlinge bedienings, oftewel korporatiewe dienswerk, bou die gelowiges mekaar op. Die liggaam van Christus word die instrument, die kanaal waardeur die bediening van Christus hier op aarde voortgesit word. Volgens Langerman (1983:9) vind die bediening van die kerk in drie fases plaas. Die dissipels is eers geroep, daarna toegerus en uiteindelik uitgestuur om die koninkryk te verkondig. Hierdie roeping is tweeledig van aard, naamlik intern en ekstern.

\section{- Interne roeping}

Snyder (1977:73) verklaar dat die vroeë kerk besig was met twee belangrike take:

- Die verkondiging van die evangelie. Evangelisasie was die natuurlike gevolg van die teenwoordigheid van die Christengemeenskap in die wêreld.

- Die opbou van die gemeenskap van die gelowiges. Die vyfvoudige (of viervoudige: apostels, profete, evangeliste en herderleraars) bediening is aan die kerk gegee vir die opbou van die gelowiges, sodat gelowiges hulle dienswerk kan verrig.

\section{- Eksterne roeping}

Langerman (1983:14) verklaar dat die kerk volgens die gesig van Jesaja (Jes. 6) ook 'n eksterne roeping het. Hy stel dit dat iemand die vraag in Jesaja 6:8: "Wie sal vir My gaan en wie sal ek stuur?" behoort te beantwoord. Die identiteit van die kerk behoort in wese missionêr te wees (Bosch, 1991:392). Ons is na God se beeld geskape (vgl. Gen. 1:26-28) en is dus lede van sy liggaam (vgl. Ef. 4:11-16). Volgens Hendriks (2004:25) bestaan die gemeenskap van gelowiges uit lidmate wat deelneem aan God se voortgaande missionêre opdrag aan hulle vir die wêreld (vgl. Matt. 28:19). 'n Geloofsgemeenskap bestaan uit dissipels wat deelneem aan God se missionale praxis. As sodanig behoort gemeentes se antropologie en ekklesiologie ' $n$ diepsinnige missionêre basis te inkor- 
poreer. Die gebed, "laat U koninkryk kom," vra 'n missionêre praxis in gemeentes (Hendriks, 2004:32).

Murphy (1975:190) definieer die eksterne roeping van die kerk soos volg:

The mission of the church is to establish a rapport with people by our presence among them. Then we proclaim the Gospel to them. This implies to persuade them to make a clear-cut decision for Christ. Finally, we work to incorporate them into worshipping groups.

\subsubsection{Potensiaal van lidmate}

Om lidmate optimaal te mobiliseer om hulle plek en funksie in die liggaam van Christus op te neem, sal dit nodig wees om elke lidmaat se potensiaal te ontdek en te ontwikkel. Met die begrip potensiaal word aan mense se talente, gawes of vaardighede gedink - die latente vermoëns waaroor lidmate beskik en wat, indien dit geaktiveer word, aangewend kan word om belangrike doelstellings te bereik.

Die vraag is of pastore wel die talente, gawes, vaardighede of potensiaal van die lidmate raaksien. Indien wel, kan hulle dit ontwikkel tot uitbreiding van die koninkryk? Volgens Botha (1999:24-25) het alle lidmate potensiaal en ontwikkelingsmoontlikhede (Schwarz, 2001:42). God het as Skepper 'n bepaalde potensiaal in alle lidmate geplaas en lidmate behoort te ontwikkel om daardie volle godgegewe potensiaal te ontsluit.

\subsubsection{Karakter van die potensiaal}

Die potensiaal wat God in lidmate plaas, stel hulle in staat om deur die inspirasie en krag van die Heilige Gees as God se verteenwoordigers op aarde te funksioneer. Barclay (1976:31) meen dat God mense as sy instrumente gebruik om die goeie nuus te versprei. Derhalwe gee God 'n verskeidenheid genadegawes aan lidmate om in diens van die koninkryk te staan.

Genadegawes stel lidmate in staat om onder leiding van die Heilige Gees spesiale take tot opbou van die gemeente te verrig. ${ }^{2}$ Alle lede van die liggaam het minstens een geestelike gawe ontvang (Schwarz, 2001:42). Schwarz beweer dat tot $80 \%$ van alle Christene

2 Spesiale take word gesien in die lig van algemene dienswerk. 
onseker is oor hulle gawes. Dit gee aanleiding tot, soos hy dit beskryf, die kritieke toestand in die kerk. As 'n gemeente wil groei, behoort pastore dringend aandag te skenk aan die toerusting van hulle lidmate. Doelmatigheid word sigbaar wanneer elke lidmaat van 'n gemeente by dienswerk betrokke is.

Daar is 'n behoefte in gemeentes na meer deeltydse werkers. 3 Conner (2000:107-108) meen dat die groei in gemeentes bepaal word deur die vermoë van 'n leier om deur mense te werk.

\subsubsection{Ontwikkeling van lidmaatpotensiaal}

By wetenskaplikes is wyd uiteenlopende benaderingsverskille wanneer dit kom by ontwikkelingsteorieë, juis omdat wetenskaplikes die probleem vanuit verskillende hoeke benader. Meyer en Van Ede (1990:51) wys daarop dat hierdie verskille in wese gegrond is in die mensbeskouing wat as uitgangspunt geneem word. Hulle is van mening dat optimaal ontwikkelde persone die vermoë het om hulle potensiaal ten volle te ontwikkel. Murphy (1975:37) dui aan dat daar nie onbegaafde lidmate is nie - met ander woorde alle mense het potensiaal van God ontvang om dienswerk te verrig. Potensiaal dui op latente vermoëns wat, indien dit geaktiveer word, aangewend kan word om sekere doelstellings na te streef. Ontwikkeling dui daarop dat dit analoog is aan die ontwikkeling van 'n foto vanuit 'n negatief. Die volle potensiaal en eienskappe van die finale foto lê in die negatief opgesluit, maar die potensiaal wat in die film vasgelê is, moet eers ontwikkel word voordat die volkome beeld bereik kan word.

Volgens Botha (1999:45) kan hierdie twee begrippe saamgevoeg word. Potensiaalontwikkeling kan gedefinieer word as die proses waardeur die latente vermoëns van mense ontwikkel word. Die potensiaalontwikkelingsproses is 'n voortdurende proses, aangesien alle mense voortdurend in 'n proses van groei en verandering is. In die lig van hierdie artikel beteken dit dat mense se ingeboude of latente geestelike gawes sodanig ontwikkel behoort te word dat hulle uiteindelik sinvol God se doel met hulle lewens kan bereik.

3 Met "deeltydse werkers" word gewone lidmate bedoel wat in dienswerk in die gemeente of elders betrokke is. 


\section{Gawes en bediening}

Gawes en bediening is nodig vir die uitvoer van die sendingopdrag soos dit in Matteus 28:19 uiteengesit is. Om aan die roeping en uitvoering van die kerk se missionêre opdrag gehoor te gee, is daar volgens die apostel Paulus aan elke lidmaat 'n gawe(s) gegee met die oog op die bediening van die liggaam en om die wêreld te bereik (Murphy, 1975:xi). In aansluiting hiermee verklaar 1 Petrus 4:10: "As goeie bedienaars van die veelvoudige genade van God moet elkeen, namate hy 'n genadegawe ontvang het, die ander dien."

Talle skrywers, waaronder Stedman (1972:38), MacArthur (1973: 133) en Banks (1980:63) stem saam dat alle lidmate in 'n gemeente 'n gawe(s) ontvang het en verantwoordelikheid behoort te aanvaar om dit tot heil van die gemeente uit te leef. Möller (1983:50) meen dat elke geestelike gawe gegee word met die oog op een of ander funksie wat in die liggaam van Christus verrig moet word. Schwarz $(2001: 43)$ is van mening dat die verklarings in die Nuwe Testament aangaande die geestelike gawes in die konteks van die groei van die liggaam van Christus gesien moet word. Geestelike gawes word primêr tot voordeel van andere gegee.

\subsection{Verskeidenheid van genadegawes}

Die woord charisma is 'n breë en omvattende woord vir genadegawes, 'n guns wat iemand ontvang sonder enige verdienste van hulle eie (Möller, 1997:57). Dit gaan om die totaliteit van God se genadebetoning aan die mens, in besonder God se fundamentele gawe van verlossing aan die mens.

Elke gawe is 'n manifestasie van sy genade (Gaffin, 1979:47). God realiseer sy genade aan mense deur gawes aan hulle te skenk. Geestelike gawes is met die oog op een of ander funksie wat in die gemeente verrig moet word.

Paulus se bedoeling met die noem van die besondere gawes in Efesiërs 4:11 was nie om 'n volledige lys van dienste weer te gee nie. Dit gaan oor geskikte persone wat deur die Heilige Gees daargestel is om bepaalde take en dienste te verrig en mense wat deur die Heilige Gees met gawes toebedeel is.

In sistematiese studies het dit die norm geword om die gawes te kategoriseer. Skrywers het hulle eie perspektiewe rondom die saak en daar bestaan nie eenstemmigheid nie. Groepering kan op verskeie maniere plaasvind, afhangende van watter uitgangspunt 'n skrywer het. Volgens MacGorman (1974:35) is die klassifisering van 
die gawes nie vanuit die Skrif gefundeer nie. Nêrens poog die Skrif om die gawes te klassifiseer nie.

Van Schalkwyk (1988:29) waarsku dat die vrymag van God nie aan bande gelê moet word deur die kategorieë waarin die gawes van die Heilige Gees geplaas word nie. Dit blyk uit die bestudering van die Nuwe Testament dat sekere gawes nouer met mekaar skakel as ander; daar is oorvleueling en ineenvloeiing. Sekere gawes word saam geklassifiseer vanweë die aard en funksionering daarvan, alhoewel die gawes in hulle oorsprong, inherente wese en uiteindelike doelstelling volkome gelykwaardig is. Met die liggaam-van-Christusmetafoor word die interafhanklikheid en onderlinge belang van die gawes beklemtoon in die sin dat alle gawes essensieel vir die gesonde funksionering van die gemeente is.

Daar bestaan nie 'n "hoër"- of "laer"-klas gelowiges nie, soos daar ook nie eksklusiewe voorkeurgawes bestaan nie. Alle gelowiges behoort dus 'n bydrae tot diens in die gemeente te lewer. Die wese van die dienswerk maak ook geen verskil tussen die lidmaat en die ampsdraer nie. Alle gelowiges beoefen hulle dienswerk deur middel van hulle gawes.

God gee aan individuele gelowiges verskillende gawes om verskillende dienste op 'n diversiteit van diensterreine te verrig. Alle gelowige beoefen hulle eie unieke funksie(s) ooreenkomstig die gawes(s) wat hulle ontvang.

\subsection{Verskeidenheid van bedienings}

Van den Berg (1991:24) is van mening dat 'n latente genadegawe in die praktyk van weinig nut vir die koninkryk van God is as dit nie beoefen word nie. Die oomblik wanneer hierdie gawe egter beoefen word, vind bediening plaas, hetsy binne of buite gemeentelike verband, of dit deur die gemeente erken word of nie en of dit kortstondig, sporadies of voortdurend van aard is. Die ideaal is dat die beoefening daarvan op ' $n$ voordurende basis sal wees en dat dit deur die gemeente erken en bevestig word.

Fenhagen (1977:134) stel dit dat die liggaam alleenlik gesond sal wees wanneer die gelowige aktief betrokke is met die funksies waartoe God hulle geroep het. Die liggaam behoort soos 'n liggaam te funksioneer waar elke lid as belangrik geag word. 


\subsection{Verskeidenheid van werkings}

Stedman (1972:42) definieer die verskeidenheid van werkings as volg: "The term refers to the degree of power by which a gift is manifested or ministered on a specific occasion, and also to which gift manifests through whom on what occasion."

Dit is die prerogatief van God om te bepaal wat deur die verskillende bedienings en die beoefening van die gawes vermag moet word. So byvoorbeeld het Johannes die Doper nie een wonderwerk gedoen nie. Nogtans verklaar Jesus in Matteus 11:11 dat daar onder dié wat uit vroue gebore is, nie een opgestaan het wat groter as hy is nie. God bepaal deur wie Hy watter gawe wil gee. Vervolgens enkele gedagtes rondom die praktiese implikasie van die liggaam-vanChristus-metafoor.

\section{Bediening van die lidmaat op die voorgrond}

Klemverskuiwings maak dit nodig vir die kerk om indringend haar selfverstaan te hersien en 'n nuwe prakties-teologiese ekklesiologie te ontwikkel.

Onder 'n prakties-teologiese ekklesiologie word 'n metafoor vir kerkwees verstaan wat nie soseer op die wese van die kerk konsentreer nie, maar op die lewe van die kerk. Dit is 'n poging om die wese van die kerk in terme van haar funksie te verstaan.4 'n Praktiesteologiese ekklesiologie toets die konfessionele basis van die kerk krities aan die gehalte, kwaliteit en volwassenheid van lidmate wat in die wêreld gestalte moet gee aan die boodskap van die kerk. Die vraag is nie of mense aan die ware kerk behoort nie, maar eerder of hulle ware en lewende lidmate van die kerk is (Louw, 1992:121).

Navorsing toon dat dit vir die praktiese teologie noodsaaklik is om die kerk te help deur middel van situasie-analises en interpretasies asook empiriese beskrywings van kerklike prosesse om haar bedieningsfunksies beter te verstaan (Burger, 1991:93-94). Vanweë die toenemende proses van sekularisasie, vertegnisering, rekenarisering, meganisering en kommersialisering bestaan tans ' $n$ toenemende behoefte by mense aan humaniteit en intimiteit. Met die oog op hierdie belangrike eksistensiële behoeftes kies die praktiesteologiese ekklesiologie die liggaam-van-Christus-metafoor. Die

$4 \quad$ Onder funksie word die diensgestaltes van die kerk verstaan as ontmoetinggestaltes van die heil en kommunikatiewe geloofshandelinge. 
verstaan van die kerk as liggaam-van-Christus gee die beste uitdrukking aan die primêre funksie van die kerk in die 21e eeu. Daar is 'n verwagte toename in probleme soos armoede en geweld en die uitleef van die funksie van die kerk deur versorging, diens en gemeenskap (Louw, 1992:124).

In die liggaam-van-Christus-metafoor tree die pastoor op die agtergrond en word die bediening van die lidmaat herstel. Waar lidmate se bydrae moontlik voorheen as minderwaardig beskou is, val die klem in die liggaam-van-Christus-metafoor op die priesterlike bediening en geestelike gesag van die gelowiges (Mark. 16:17; 1 Pet. 2:9; Op. 5:10).

Die gaping tussen pastore en lidmate het oor jare ontwikkel omdat die kerk van die Bybelse patroon van gemeentewees afgewyk het. Die kerk het 'n instituut en organisasie geword in plaas van 'n organisme. Dit het al meer gegaan om die elite, titels, status en professionalisme. Een van die grootste struikelblokke wat die plaaslike gemeente verhinder om as liggaam van Christus te funksioneer, is die onderskeid wat gemaak word tussen "geestelikes" en "lidmate." Alle Christene is geroep om volk van God te wees (vgl. 1 Kor. 1:2; Ef. 4:1, 4; 2 Tim. 1:9). Daarom is alle mense veronderstel om dienswerkers te wees. Daar word gepleit vir 'n nuwe benadering in verband met die identiteit en bediening van die lidmaat. Alle lidmate behoort die volle voorreg van verantwoordelikheid te geniet terwyl hulle met dienswerk betrokke is.

\subsection{Die rol van die pastoor}

Heyns (1986:13) beskryf die rol van die herder in die herderkuddemodel - 'n voorbeeld van 'n meer institusionele struktuur. Hy wys daarop dat van die herder verwag word om prominent die inisiatief en leiding te neem, ondernemingsgees aan die dag te lê en die gemeente te versorg en te lei. Die kudde is die gemeente wat in vertroue en afhanklikheid die herder gehoorsaam volg. Volgens Van den Berg (1991:1) is die pastoor die spil waarom die funksionering, aktiwiteite en bediening van 'n gemeente draai. Hy/sy is tegelyk herder, leraar, evangelis, sieketrooster, administrateur, organiseerder, instandhouer, pastorale konsultant en algemene voorligter, terwyl die res van die gemeente dikwels passief is of raak.

Die klem op dienswerk van die gelowiges en die ontwikkeling van die individuele gawes is gemik op die regstelling van 'n fundamentele probleem, "klerikalisme". Selfs die Reformasie kon nie die juk daarvan afskud nie. Indien teologie op die vlak van lidmate 
beoefen word, is betrokkenheid deur middel van dade en diens in praktyk missionêr en word die gemeente ook in die proses opgebou (Hendriks, 1994:187-188).

In die klassieke reformatoriese model is die ampsdraers op gelyke vlak met die gemeentelede en is daar geen sprake van 'n hiërargie of ampsbemiddeling nie. Die ampsdraers tree nie bemiddelend tussen Christus en die gemeentelede op nie, omdat die gemeente in 'n direkte verhouding tot Christus staan, anders as in die RoomsKatolieke model. Christus regeer die gemeente. Hy roep steeds ampsdraers en maak van hulle gebruik. Hierdie ampsdraers tree nie uit hulself op nie, maar verteenwoordig Christus.

Krities beoordeel sou met reg gesê kan word dat die besondere ampte as essensieel beskryf kon word. 5 Die belangrikste rede waarom die besondere amp binne die gereformeerde kerke as essensieel beskryf kan word, is omdat die amp in die Skrif gefundeer word en nie van tyd en omstandighede afhanklik gemaak kan word nie. Oor die feit dat die besondere ampte as instelling 'n Bybelse gegewe is, is daar ook geen onduidelikheid nie (Heyns, 1992:54).

Versteeg (1988:49-53) beklemtoon eweneens die essensie van die besondere amp, deur 'n onderskeid te tref tussen amp en diens. Alle gelowiges is tot diens geroep, maar alle dienswerk het nie 'n amptelike karakter nie. Versteeg (1988:53) stel dit: "leder ampte is een dienste, maar niet iedere dienste is een ampte."

In Efesiërs 4:11-12, kry diens, volgens hom, 'n amptelike karakter wanneer dit daarop gerig is om ander gelowiges (vgl. Ef. 4:11 heiliges) te help om vrywillige dienswerk te verrig. Versteeg (1988: 53) stel dit dat die werk van ampsdraers die karakter het "van een dienst ten dienste van het dienen van alle anderen in die kerk".

Dit is hierdie gerigtheid van die diens van ampsdraers op medegelowiges wat die diens van sommige tot amp maak. Versteeg vergelyk die taak van ampsdraers in die gemeente met die funksie van 'n sening. Net soos die sening die skelet verbind, so verbind die besondere ampte die verskeidenheid dienste binne die liggaam van Christus en tree sodanig koördinerend op. Die besondere ampte verseker dat die dienste van lidmate sinvol gekoördineer word en

5 Die besondere amp verwys na die leierskap (vyfvoudige bediening) wat verantwoordelik en nodig is om gelowiges vir hulle dienswerk toe te rus. 
nie kontraproduktief is nie. Die besondere ampte werk ook stimulerend en vormend. Net soos die sening die draers van kanale is waardeur die liggaam gevoed word, so voed die besondere ampte die liggaam van Christus. Versteeg (1988:57) is van mening dat die diens van gelowiges afhanklik is van die besondere ampte. Hy gaan sover om te sê: "... zo kan en zonder de dienst van de ambtsdragers geen functioneren van de gelovigen zijn”.

In die reformatoriese model word die besondere ampte en die gemeente duidelik van mekaar onderskei, maar daar is teologies geen waarde-onderskeid nie. Die besondere ampte en die gemeente staan in ' $n$ afhanklike verhouding tot Christus. Tog word daar ' $n$ bepaalde gesag aan die besondere ampte gegee, soos gesimboliseer in hulle ordening en bevestiging. Dit lei dikwels in die praktyk tot die ontwikkeling van "klerikalisme" en "hiërargieë".

\subsection{Organisasie en strukture}

Die liggaam-van-Christus-metafoor sluit nie organisering en strukture uit nie. Dit verskil van die meer institusionele kerk in die volgende opsig:

- Die institusionele model word nie tot die primêre verhef nie, maar dien op sekondêre vlak die liggaam van Christus.

- Die besondere ampte in die kerk word nie hiërargies bepaal nie, maar is funksioneel volgens die gawes wat Christus gee.

- Die onderskeid tussen die besonder ampte en die lidmate val weg.

- Die gawes van lidmate word geïdentifiseer en elkeen word opgelei om hulle bediening in die liggaam van Christus te vervul.

Deemer (1976:94) verklaar:

As the church sees itself more and more as the body of Christ, it will grow, strengthen, prosper, and lead its people; and it won't have to worry about preserving the institution ... I can envision nothing in the church of the future that would contribute more to its healthy spiritual growth.

\section{Samevatting}

Baie AGS-pastore is so besig met 'n veelheid take en verantwoordelikhede dat hulle nie daarby uitkom om hulle lidmate effektief te mobiliseer om by vrywillige dienswerk (vgl. Ef. 4:12) betrokke te 
raak nie. Gevolglik staan die meerderheid lidmate passief teenoor vrywillige dienswerk. Hierdie toedrag van sake behoort dringend deur die kerkleierskap hanteer te word (vgl. Eks. 18).

'n Nuwe praxis beklemtoon dat indien AGS-pastore meer op die ontdekking van gawes en toerusting van lidmate vir vrywillige dienswerk sal fokus, gemeentes hulleself onderling (intern) pastoraal beter kan versorg en terselfdertyd hulle (eksterne) missionêre roeping vervul.

Die liggaam-van-Christus-metafoor word as 'n Bybelse instrument vir die effektiewe uitvoering van die missionale opdrag voorgestel, hetsy intern of ekstern (Murphy, 1975:267-276). Lidmaatpotensiaal, die karakter en veral die ontwikkeling daarvan word as 'n noodsaaklikheid vir die effektiewe uitvoering van die missionêre opdrag beskou.

Die bedieningsmetafoor vir vrywillige dienswerk wat in hierdie artikel bespreek is, is bedoel om sekere paradigmaskuiwe, strukturele veranderings en nuwe benaderings tot die bestuur van die prosesse voor te stel. Die implementering daarvan sal meewerk tot die effektiewe funksionering van die liggaam-van-Christus-metafoor, soos vervat in Efesiërs 4:11-16. 'n Verder gevolg sal wees dat gemeentes sodanig gestruktureer word om die potensiaal van lidmate te ontdek, te ontwikkel en hulle te ondersteun om in die liggaam van Christus effektiewe vrywillige dienswerk te doen.

\section{Geraadpleegde bronne}

BANKS, R. 1980. Paul's idea of community. Exeter: Paternoster.

BARCLAY, W. 1976. The letters to the Galatians and Ephesians. Edinburg: St. Andrew.

BEKER, J.C. 1989. Paul, the apostle. Edinburgh: Clark.

BISSCHOFF, J. 1993. Die spanning tussen die versoenings- en missionêre dimensie in gemeentebou. Praktiese teologie in Suid-Afrika, 8(1):42-56.

BOSCH, D.J. 1991. Transforming mission: paradigm shifts in theology of mission. New York: Orbis.

BOTHA, F.P.J. 1999. 'n Bestuursmodel vir potensiaalontwikkeling en toerusting van die lidmate van die AGS. Johannesburg: Randse Afrikaanse Universiteit. (M.Th.-verhandeling.)

BURGER, C.W. 1991. Die dinamika van 'n Christelike geloofsgemeenskap. Kaapstad: Lux Verbi.BM.

COMBRINK, V. \& VENTER, C.J.H. 1995. Menslike subjekte in gemeente opbou volgens die Kolossensebrief. In die Skriflig, 29(4):583-602.

CONNER, M. 2000. Transforming your church. Ventura: Renew.

DEEMER, P. 1976. Fulfilling the body of Christ. (In Strough, F.C. \& Strough, U.T., eds. Realities and visions. New York: Seabury. p. 92-98.) 
FENHAGEN, J.C. 1977. Mutual ministry. New York: Seabury.

GAFFIN, R.B. 1979. Perspectives on Pentecost. Phillipsburg: Presbyterian \& Reformed.

GOEDE, H. 2007. 'n Toepaslike metafoorteorie vir die ontleding van die metafore in die Nuwe Testament. In die Skriflig, 41(1):87-107.

GUDER, D.L. 1998. Missional church: a vision for the sending of the church in North America. Grand Rapids: Eerdmans.

HENDRIKS, H.J. 1992. Strategiese beplanning in die gemeente: beginsels in die praktyk van gemeentevernuwing. Wellington: Hugenote.

HENDRIKS, H.J. 1994. Missionêre gemeentebou. Praktiese teologie in SuidAfrika, 9(2):180-191.

HENDRIKS, H.J. 2004. Studying congregations in Africa. Paarl: Paarl.

HEYNS, J.A. 1977. Die kerk. Pretoria: NG Kerkboekhandel.

HEYNS, L.M. 1986. 'n Prakties-teologiese ondersoek na die kerklike strukture van die Nederduitse Gereformeerde Kerk. Pretoria: Universiteit van SuidAfrika. (D.Th.-proefskrif.)

HEYNS, L.M. 1992. Die besondere amp: essensieel of funksioneel? Theologia evangelica, 25(3):52-58.

HEYNS, L.M. \& PIETERSE, H.J.C. 1990. Eerste treë in die praktiese teologie. Pretoria: Gnosis.

JANSE VAN RENSBURG, F.J. 1999. Efesiërs. (In Vosloo, W. \& Janse van Rensburg, F., reds. Die Bybellennium: eenvolumekommentaar. Vereeniging: Christelike Uitgewersmaatskappy. p. 1567-1580.)

KRAEMER, H. 1958. A theology of the laity. London: Butterworth.

KRAEMER, H. 1960. Het vergeten ambt in de kerk. 's Gravenhagen: Boekencentrum.

LANGERMAN, J.L. 1983. Apostolic faith mission of South Africa: a revitalization of the theological concepts of church ministry. Johannesburg: Fuller Theological Seminary. (D.Min. dissertation.)

LAZENBY, M.J. 1995. Kerklike lidmaatskap: prakties teologies verken. Praktiese teologie in Suid-Afrika, 10(1):15-28.

LOUW, D.J. 1992. Die ontwerp van 'n prakties-teologiese ekklesiologie vir gemeentebou. Praktiese teologie in Suid-Afrika, 7(2):119-136.

LOUW, P.L. 1990. 'n Beskrywing van die gemeentebouproses in die Nederduitse Gereformeerde Gemeente Burgersdorp 1985-1989. Stellenbosch: Universiteit van Stellenbosch. (M.Th.-verhandeling.)

MACARTHUR, J. 1973. The church, the body of Christ. Grand Rapids: Zondervan.

MACGORMAN, J.W. 1974. The gifts of the Spirit. Nashville: Broadman.

MEYER, W.F. \& VAN EDE, D.M. 1990. 2e dr. Ontwikkelingsteorieë. (In Louw, D.A., red. Menslike ontwikkeling. Pretoria: HAUM. p. 51-99.)

MÖLLER, F.P. 1983. Poimeniek. Johannesburg: AGS Teologiese Seminarium.

MÖLLER, F.P. 1997. Words of light and life: the work of the Holy Spirit in the life of the believers. Vol. 6. Hatfield: Van Schaik.

MURPHY, E.F. 1975. Spiritual gifts and the great commission. South Pasadena: Mandate.

NEL, M. 1994. Gemeentebou. Halfway House: Orion.

RICHARDS, L.O. \& HOELDTKE, C. 1981. A theology of church leadership. Grand Rapids: Zondervan.

SCHWARZ, C.A. 2001. The three colours of ministry. Barcelona: Zondervan.

SNYDER, H.A. 1977. The community and the King. Madison: InterVarsity. 
STEDMAN, R.C. 1972. Body life. Ventura: Regal.

VAN DEN BERG, C.J. 2000. Tersaaklike Pauliniese perspektiewe op die Christelike identiteit van die lidmaat. Johannesburg: Randse Afrikaanse Universiteit. (M.Th.-verhandeling.)

VAN DEN BERG, J.C. 1991. Die pastoor en lidmaat in die Apostoliese Geloof Sending van Suid-Afrika: strukturele fasette en bedieningsmodelle. Pretoria: Universiteit van Suid-Afrika. (M.Th.-verhandeling.)

VAN SCHALKWYK, J. 1988. Gemeentebou - ons opdrag. Kaapstad: NG KerkUitgewers.

VERSTEEG, J.P. 1988. Het karakter van het ambt volgens Efesiërs 4:7-16. (In Rossouw, P.J., red. Gereformeerde ampsbediening. Pretoria. NG Kerkboekhandel. p. 47-74.)

WARREN, R. 1995. The purpose driven church. Michigan: Zondervan.

WOODS, C.J. 1996. Congregational mega trends. New York: The Albian Institute.

\section{Kernbegrippe:}

lidmaatpotensiaal: talente, gawes, vaardighede, latente vermoëns liggaam van Christus: missionale opdrag, effektiewe uitvoering van metafoor

\section{Key concepts:}

body of Christ: missional commission, effective execution of metaphor

member potential: talents, gifts, skills, latent abilities 
